\title{
Mode of Action of Anhydrofulvic Acid against Candida utilis ATCC 42402 under
}

\author{
Acidic Condition
}

\author{
Ken-Ichi Fujita*, Yasuko Nagamine, Xu Ping and Makoto Taniguchi \\ Department of Bio- and Geoscience, Graduate School of Science, Osaka City University, \\ 3-3-138 Sugimoto, Sumiyoshi-ku, Osaka 558-8585, Japan
}

(Received for publication February 1, 1999)

\begin{abstract}
The mode of action of anhydrofulvic acid against Candida utilis ATCC 42402 was investigated under acidic conditions. Anhydrofulvic acid inhibited the incorporation of radioactive precursors into DNA, RNA, protein and lipid fractions. Although it did not induce leakage of intracellular materials from the treated cells, it had inhibitory effects on both endogenous and exogenous cellular respiration. Moreover, it inhibited mitochondrial respiration of Candida utilis ATCC 42402 using both succinate and cytochrome $c$ as respiratory substrates, but not using NADH. Unexpectedly, the inhibition against isolated mitochondria was observed at $\mathrm{pH}$ 7.0. These results suggested that the action site against the respiratory inhibition of anhydrofulvic acid might be involved in succinate dehydrogenase, complex II in the mitochondrial electron transport chain of the yeast cells. Judging from the inhibitory effect of anhydrofulvic acid on mitochondria detected at $\mathrm{pH} 7.0$, it was postulated that the antifungal activity at a low $\mathrm{pH}$ level might depend on the elevation of drug permeability to the cell membrane under acidic conditions.
\end{abstract}

In the course of our screening program of antifungal antibiotics, the fungus Penicillium afacidum was found to produce an antibiotic which exhibited an antifungal activity under acidic conditions in a culture medium. The antibiotic, purified from the culture broth, was identified as anhydrofulvic acid by physico-chemical studies. Although we found another derivative of anhydrofulvic acid, fulvic acid, in the culture broth, fulvic acid showed relatively little antifungal activity against tested strains. It has been reported that anhydrofulvic acid can be chemically obtained by sublimation of fulvic acid ${ }^{1)}$, which was isolated from several kinds of fungi ${ }^{2,3)}$. However anhydrofulvic acid has not been derived from natural resources. Moreover, the biological activity of anhydrofulvic acid has not yet been reported. In this study, we described the antifungal mechanism of this compound on the Candida utilis ATCC 42402 strain, which was the most susceptible fungi among all tested strains.

\section{Materials and Methods}

\section{Isolation of Anhydrofulvic Acid}

The fungus Penicillium afacidum, isolated from a soil sample collected at the Sugimoto campus of Osaka City University, was found to produce anhydrofulvic acid as described below. Anhydrofulvic acid was produced in a culture broth of Penicillium afacidum cultivated for five days at $25^{\circ} \mathrm{C}$ in a 5 -liter jar fermenter containing 3 liters of $2.5 \%$ malt extract medium which was adjusted to $\mathrm{pH} 4.0$ using a Mcllvaine buffer. The active fractions containing anhydrofulvic acid were monitored using a paper disc method. The culture filtrate was adjusted to $\mathrm{pH} 2.0$ using $0.1 \mathrm{~N} \mathrm{HCl}$ and subjected to a Diaion HP-20 column. The active fractions containing anhydrofulvic acid were once again monitored using the paper disc method. After the HP-20 resin was washed in $50 \%$ methanol $(\mathrm{v} / \mathrm{v})$, the portions containing anhydrofulvic acid were eluted with methanol. The portions which were evaporated to dryness were then dissolved in chloroform and extracted into water at $\mathrm{pH} 9.0$. The extract was adjusted to $\mathrm{pH} 3.0$ and then extracted in chloroform. The extract obtained was concentrated in vacuo and purified using silica gel column chromatography, in 
which elution was performed using chloroform containing an increasing ratio of methanol $(0 \sim 5.0 \%)$. Anhydrofulvic acid was eluted in chloroform containing $1 \%$ methanol and fulvic acid in chloroform containing 5\% methanol. Anhydrofulvic acid was recrystallized as yellow prisms in dimethylformamide-water. However, fulvic acid was recrystallized as yellow needles in chloroform-methanol. The chemical structures of these compounds were elucidated as the following at $400 \mathrm{MHz}$ for ${ }^{1} \mathrm{H}$ NMR and $100 \mathrm{MHz}$ for ${ }^{13} \mathrm{C}$ NMR. Anhydrofulvic acid; mp 237 to $242^{\circ} \mathrm{C}$; $\mathrm{MS}\left(\mathrm{M}^{+}\right) ; m / z: 290.0427$ (Calcd. for $\mathrm{C}_{14} \mathrm{O}_{10} \mathrm{O}_{7}: 290.0427$ ); IR $\left(\mathrm{cm}^{-1}\right)$ 3200, 2800 2300, 1640, 1620; ${ }^{1} \mathrm{H}$ NMR (dimethyl sulfoxide [DMSO] $d-6) \quad \delta 1.99(3 \mathrm{H}, \quad \mathrm{s}, 3-\mathrm{Me}), 5.67$ $(1 \mathrm{H}, \mathrm{s}, 4-\mathrm{H}), 6.91(1 \mathrm{H}, \mathrm{s}, 6-\mathrm{H}), 5.15\left(2 \mathrm{H}, \mathrm{s}, 1-\mathrm{H}_{2}\right) ;{ }^{13} \mathrm{C}$ NMR (DMSO d-6) (61.06 (C-1), 167.53 (C-3), 94.15 (C-4), 158.50 (C-4a), 151.85 (C-5a), 103.38 (C-6), 149.72 (C-7), 144.29 (C-8), 112.67 (C-9a), 171.05 (C-10), 101.08 (C-10a), $19.75(\mathrm{Me}), 168.78(\mathrm{COOH})$. Fulvic acid; ${ }^{1} \mathrm{H}$ NMR (DMSO $d-6) \delta 1.46(3 \mathrm{H}, \mathrm{s}, 3-\mathrm{Me}), 2.58(1 \mathrm{H}, \mathrm{d}, J=17.7 \mathrm{~Hz})$, $2.88(1 \mathrm{H}, \mathrm{d}, J=17.7 \mathrm{~Hz}), 4.44\left(2 \mathrm{H}, \mathrm{s}, 1-\mathrm{H}_{2}\right), 6.90(1 \mathrm{H}, \mathrm{s}$, $6-\mathrm{H}) ;{ }^{13} \mathrm{C}$ NMR (DMSO d-6) $\delta 56.17$ (C-1), 94.06 (C-3), 37.36 (C-4), 163.92 (C-4a), 152.31 (C-5a), 102.55 (C-6), 158.58 (C-7), 150.72 (C-8), 118.08 (C-9), 113.72 (C-9a), 172.83 (C-10), 111.91 (C-10a), 28.13 (Me), 168.00 (COOH).

\section{Antifungal Assay}

The antifungal activity of anhydrofulvic acid and fulvic acid was determined using a serial broth dilution method. The yeasts and fungi were cultivated in $2.5 \%$ malt extract medium containing $0.01 \mathrm{M}$ tartrate buffer $(\mathrm{pH} 3.0$ ) for 2 days at $25^{\circ} \mathrm{C}$. Several biological activities of anhydrofulvic acid were marked at this $\mathrm{pH}$ as follows. Under this acidic condition, therefore, succeeding experiments were conducted unless otherwise stated. The test strains listed in Table 1 were purchased from the Institute Fermentation Osaka, IFO (Osaka, Japan) and the American Type Culture Collection, ATCC (Rockville, U.S.A.). The MIC values were defined as the lowest concentration of anhydrofulvic acid which showed no visible growth.

Incorporation of Radioactive Precursors into

\section{Macromolecules}

The strain of $C$. utilis ATCC 42402 was cultivated in a GYE medium containing $2.0 \%$ glucose and $1.0 \%$ yeast extract with shaking at $25^{\circ} \mathrm{C}$ for 16 hours. After the cells were harvested by centrifugation, they were reinoculated into a diluted GYE medium containing $0.8 \%$ glucose, $0.4 \%$ yeast extract, and $10 \mathrm{~mm}$ tartrate buffer ( $\mathrm{pH} \mathrm{3.0)}$ to give $2.0 \times 10^{6} \mathrm{CFU} / \mathrm{ml}$. The suspension was precultivated at $28^{\circ} \mathrm{C}$ for 15 minutes and then $\mathrm{L}-\left[1-{ }^{14} \mathrm{C}\right]$-leucine (into protein), $\left[8-{ }^{14} \mathrm{C}\right]$-adenine (into nucleic acid), or $\mathrm{D}-\left[{ }^{14} \mathrm{C}\right]$-glucose was added to give a final concentration of $0.4 \mathrm{KBq}^{4}$. In the case of $\mathrm{D}-\left[{ }^{14} \mathrm{C}\right]$-glucose, the concentration of cold glucose in the GYE medium was reduced to $0.2 \%$. After addition of radioactive precursors, the suspension was incubating at $28^{\circ} \mathrm{C}$ for 10 minutes, and then Anhydrofulvic acid was added to the suspension ${ }^{6)}$. After a further period of incubation, $1 \mathrm{ml}$ of the suspension was taken and placed into $1 \mathrm{ml}$ of ice cold $10 \%$ trichloroacetic acid (TCA) and held on ice for 1 hour. To measure the incorporation of adenine into DNA, the suspension was incubated in $0.1 \mathrm{~N} \mathrm{NaOH}$ at $30^{\circ} \mathrm{C}$ for 30 minutes prior to TCA treatment ${ }^{7}$. The incorporation of RNA was estimated by the difference between alkaline-untreated and -treated incorporation. The TCA precipitates were collected on glass-fiber filters (Whatman $\mathrm{GF} / \mathrm{C}$ ) and dried at $60^{\circ} \mathrm{C}$ for 16 hours. The radioactive residue left on the dried filters was counted using a Beckman liquid scintillation counter with a $5 \mathrm{ml}$ toluene-based scintillation cocktail consisting of $0.3 \% \quad 1,4$-bis-2(5-phenyloxazolyl)-benzene and $1 \%$ 2,5-diphenyloxazole ${ }^{8)}$. The incorporation of radioactive precursors into the acid-insoluble fraction in control groups was defined as $100 \%$. A portion of the extracts was transferred to the above scintillation cocktail and the radioactivity was counted.

\section{Leakage of Cellular Constituents from Cells}

Exponentially growing cells of $C$. utilis ATCC 42402 were harvested, washed with $0.9 \% \mathrm{NaCl}$ and suspended in a $50 \mathrm{~mm}$ tartrate buffer ( $\mathrm{pH} 3.0)$ to give $2 \times 10^{7} \mathrm{CFU} / \mathrm{ml}$. After preincubation for 15 minutes, the suspension was incubated with anhydrofulvic acid at $28^{\circ} \mathrm{C}$. At appropriate intervals, portions of the suspension were withdrawn and filtered. The total sugars and proteins in the supernatants were analyzed and identified as a phenolsulfate-positive and dye binding reagent-positive material, respectively ${ }^{9}$. The phenolsulfatepositive materials were determined using the method of phenolsulfate ${ }^{10)}$. The dye binding-positive materials were determined using the method of Bradford ${ }^{11}$.

\section{Cellular Respiration}

Exponentially growing cells of $C$. utilis ATCC 42402 were harvested, washed with $0.9 \% \mathrm{NaCl}$ and suspended in $50 \mathrm{~mm}$ tartrate buffer (pH 3.0) to give $2 \times 10^{7} \mathrm{CFU} / \mathrm{ml}$. After preincubation for 10 minutes, the suspension was incubated with anhydrofulvic acid at $28^{\circ} \mathrm{C}$. At appropriate intervals, portions of the suspension were withdrawn. Endogenous cellular respiration was measured with a Yanagimoto PO-100A oxygen electrode ${ }^{12)}$ in $50 \mathrm{~mm}$ tartrate buffer $(\mathrm{pH} 3.0)$. For exogenous cellular respiration, starved cells 
of the strain were prepared by incubating the washed cells in a $67 \mathrm{mM}$ phosphate buffer ( $\mathrm{pH} \mathrm{6.2)} \mathrm{with} \mathrm{shaking} \mathrm{at} 25^{\circ} \mathrm{C}$ for 22 hours. Exogenous cellular respiration was measured in $50 \mathrm{mM}$ tartrate buffer (pH 3.0) containing $50 \mathrm{~mm}$ D-glucose. In addition, to examine whether anhydrofulvic acid inhibit endogenous cellular respiration under an optimum $\mathrm{pH}$ condition for growth of yeast cells, the endogenous respiration was also measured in $67 \mathrm{~mm}$ phosphate buffer (pH 6.0).

\section{Mitochondrial Preparation}

Mitochondria were prepared from C. utilis cells using the method of BRUINENBERG et al ${ }^{13,14)}$ with a slight modification. The cells of $C$. utiltis ATCC 42402 were cultured in a medium containing $1 \%$ yeast extract, $0.18 \% \mathrm{KNO}_{3}$, and $0.5 \%$ glucose ( $\mathrm{pH} \mathrm{6.3)} \mathrm{with} \mathrm{shaking} \mathrm{at} 25^{\circ} \mathrm{C}$ for 15 hours. The washed cells were suspended into buffer A $(25 \mathrm{mM}$ potassium phosphate buffer containing $1 \mathrm{mM}$ EDTA, $1 \mathrm{~mm}$ $\mathrm{MgCl}_{2}$, and $2 \mathrm{M}$ sorbitol, $\mathrm{pH}$ 7.0) supplemented with 100 $\mathrm{mM} 2$-mercaptoethanol. The cells were washed thoroughly with distilled water and then resuspended in buffer A containing $12 \mathrm{mg} / \mathrm{ml}$ of zymolyase $20 \mathrm{~T}$ (KIRIN Brewery Co, Ltd. Tokyo, Japan). The suspension was incubated with gentle shaking at $37^{\circ} \mathrm{C}$ for 45 minutes. The spheroplast cells were washed with buffer $A$ and resuspended in $20 \mathrm{ml}$ of the same buffer. The buffer A containing $0.5 \mathrm{M}$ sorbitol was added to the suspension to give a final concentration of $0.65 \mathrm{M}$. The spheroplast cells were broken in a Dounce homogenizer with one stroke using a B-pestle. The homogenate was centrifuged at $3,000 \mathrm{~g}$ at $4^{\circ} \mathrm{C}$ for 5 minutes. The supernatant was centrifuged at $10,000 \mathrm{~g}$ for 20 minutes. The pellet harvested from spin was washed and resuspended in $25 \mathrm{~mm}$ potassium phosphate buffer ( $\mathrm{pH} 7.0$ ) containing $5 \mathrm{mM} \mathrm{MgCl}$ and $0.65 \mathrm{M}$ sorbitol. The crude mitochondrial fraction was used for the oxygen uptake assay.

\section{$\mathrm{O}_{2}$ Consumption Activity of C. utilis Mitochondria}

Mitochondrial respiration was measured in $25 \mathrm{~mm}$ potassium phosphate buffer ( $\mathrm{pH} 7.0$ ) containing $5 \mathrm{mM} \mathrm{MgCl}_{2}$ and $0.65 \mathrm{M}$ sorbitol using a Yanagimoto PO-100A oxygen electrode at $25^{\circ} \mathrm{C}$. For the $\mathrm{NADH}$ oxidase assay, $0.25 \mathrm{mM} \mathrm{NADH}$ was used as a substrate, and for the succinate oxidase assay, $2 \mathrm{mM}$ succinate and $1 \mathrm{mg} / \mathrm{ml}$ of cytochrome $c$ were used. The relative activity of the enzymes in the control groups was defined as $100 \%$.
Fig. 1. Structures of anhydrofulvic acid and fulvic acid.<smiles>CC1=Cc2oc3cc(O)c(O)c(C(=O)O)c3c(=O)c2CO1</smiles>

Anhydrofulvic acid<smiles>CC1(O)Cc2oc3cc(O)c(O)c(C(=O)O)c3c(=O)c2CO1</smiles>

Fulvic acid

\section{Results and Discussion}

\section{Antifungal Activity}

Fulvic acid is a hydroxide of anhydrofulvic acid (Fig. 1). Fulvic acid has been isolated from the cultures of Penicillium griseofulvum Dierckx ${ }^{15)}$, Carpenteles brefeldianum Dodge (Shear) ${ }^{1,15)}$, and Cercospora beticola ${ }^{3)}$ as a secondary metabolite. On the other hand, anhydrofulvic acid was obtained during the chemical synthesis of fulvic acid as a by-product ${ }^{1,16,17)}$. Isolation of this compound has not yet been reported from natural resources. The antifungal activities of anhydrofulvic acid and fulvic acid (Fig. 1) using a malt extract medium adjusted to $\mathrm{pH} 3.0$ were measured using the serial broth dilution method. Fulvic acid did not affect the growth of yeasts or fungi tested at relatively high concentrations such as $25 \mu \mathrm{g} / \mathrm{ml}$ as described in Table 1. However, it did inhibit the growth of Mucor mucedo IFO 5776 at the same concentration. Interestingly, anhydrofulvic acid showed severe growth inhibition against yeasts and fungi. We selected C. utilis ATCC 42402 strain, which was the most susceptible fungi among all those tested to investigate the antifungal mechanism of anhydrofulvic acid (Table 1).

As shown in Table 2, the elevation of the $\mathrm{pH}$ level in the medium decreased the antifungal activity of anhydrofulvic acid against $C$. utilis ATCC 42402, indicating the acidic-pH dependency of its activity. Generally, weak acids such as sorbic acid showed antifungal activity against $S$. cerevisiae at low $\mathrm{pH}$ levels thereby increasing the permeability of the acid into the cell membrane by repressing dissociation of 
Table 1. Antifungal activity of anhydrofulvic acid and fulvic acid.

\begin{tabular}{lcc}
\hline \multicolumn{1}{c}{ Microorganism } & \multicolumn{2}{c}{ MIC $(\mu \mathrm{g} / \mathrm{ml})$} \\
\cline { 2 - 3 } & Anhydrofulvic acid & Fulvic acid \\
\hline Saccharomyces cerevisiae IFO 0203 & 6.25 & $>25$ \\
Candida albicans IFO 1061 & 6.25 & $>25$ \\
C. utilis ATCC 42402 & 0.78 & $>25$ \\
Schizosaccharomyces pombe IFO 0342 & 6.25 & $>25$ \\
Hansenula anomala IFO 0136 & 6.25 & $>25$ \\
Rhizopus chinensis IFO 4745 & 3.13 & $>25$ \\
Mucor mucedo IFO 5776 & 1.56 & 25 \\
Penicillium chrysogenum IFO 4626 & 3.13 & $>25$ \\
Aspergillus niger ATCC 6275 & 6.25 & $>25$ \\
\hline
\end{tabular}

The yeasts and fungi were cultivated in a $2.5 \%$ malt extract medium containing $0.01 \mathrm{M}$ tartrate buffer $\left(\mathrm{pH} \mathrm{3.0)}\right.$ ) for 2 days at $25^{\circ} \mathrm{C}$.

Table 2. $\mathrm{pH}$ dependency of activity of anhydrofulvic acid against C. utilis ATCC 42402 .

\begin{tabular}{cc}
\hline $\mathrm{pH}$ & $\mathrm{MIC}(\mu \mathrm{g} / \mathrm{ml})$ \\
\hline 2.9 & 0.39 \\
3.5 & 0.78 \\
4.3 & 1.56 \\
6.1 & 25 \\
\hline
\end{tabular}

The cells of $C$. utilis ATCC 42402 were grown in a $2.5 \%$ malt medium containing $0.01 \mathrm{M}$ tartrate buffer adjusted to various $\mathrm{pH}$ value.

protons in the molecule ${ }^{18)}$. The principal mode of action is believed to reduce intercellular $\mathrm{pH}$ below the normal physiological range ${ }^{19)}$. However, such antifungal activity occurred at extremely high concentrations such as $400 \mu \mathrm{g} / \mathrm{ml}^{20}$. Judging from the lack of antifungal activity of fulvic acid and expression of the activity of anhydrofulvic acid at relatively low concentrations, we assumed that antifungal activity of anhydrofulvic acid was depended on other mechanisms apart from decreasing the intracellular $\mathrm{pH}$ level.

\section{Effect on Synthesis of Major Cellular Constituents}

The effect of anhydrofulvic acid on the incorporation of the specific radioactive precursors into DNA, RNA, protein, and polysaccharide of $C$. utilis ATCC 42402 cells were examined at $0.39 \mu \mathrm{g} / \mathrm{ml}$. In the control incubations, the incorporation of radioactive precursors into the acidinsoluble fractions started instantaneously, and the counts of each fraction increased almost linearly up to 90 minutes after onset of incubation. The incorporation of leucine, adenine into DNA, adenine into RNA and glucose was inhibited by 35, 63, 67 and 39\%, respectively, for 80 minutes after the addition of anhydrofulvic acid into the cell suspension. The inhibitions of incorporation in the nucleic acids seemed to be relatively potent. However, such inhibition of incorporation was thought to be secondary effect in many antibiotics, especially respiration inhibitors such as antimycine $\mathrm{A}$ and $\mathrm{UK}-2 \mathrm{~A}^{12)}$. Thus, these results did not specify the active site of anhydrofulvic acid on the yeast cells. 
Table 3. Effects of anhydrofulvic acid on endogenous and exogenous respiration activity of $C$. utilis ATCC 42402.

\begin{tabular}{|c|c|c|}
\hline \multirow[t]{2}{*}{$\begin{array}{l}\text { Anhydrofulvic acid } \\
\qquad(\mu \mathrm{g} / \mathrm{ml})\end{array}$} & \multicolumn{2}{|c|}{$\begin{array}{c}\text { Respiration activity } \\
\text { (nmoles } \mathrm{O}_{2} / \mathrm{mg} \text { dry cells } / \mathrm{min} \text { ) }\end{array}$} \\
\hline & Endogenous & Exogenous \\
\hline 0.0 & 8.1 & 11.1 \\
\hline 6.25 & 5.2 & 4.1 \\
\hline 25 & 2.7 & 3.7 \\
\hline
\end{tabular}

Cells were exposed to anhydrofulvic acid for 1 hour prior to respiration assay. Exogenous or endogenous respiration was measured in $50 \mathrm{~mm}$ tartrate buffer $(\mathrm{pH} 3.0)$ with or without $50 \mathrm{~mm}$ D-glucose, respectively.

Fig. 2. Effects of anhydrofulvic acid on endogenous respiration activity of $C$. utilis cells at $\mathrm{pH} 3.0$ and $\mathrm{pH} 6.0$.

The arrows indicated the time of the addition of anhydrofulvic acid at the following concentrations $(\mu \mathrm{g} / \mathrm{ml})$ : 0,$0 ; \triangle, 6.25 ; \bullet, 25$.

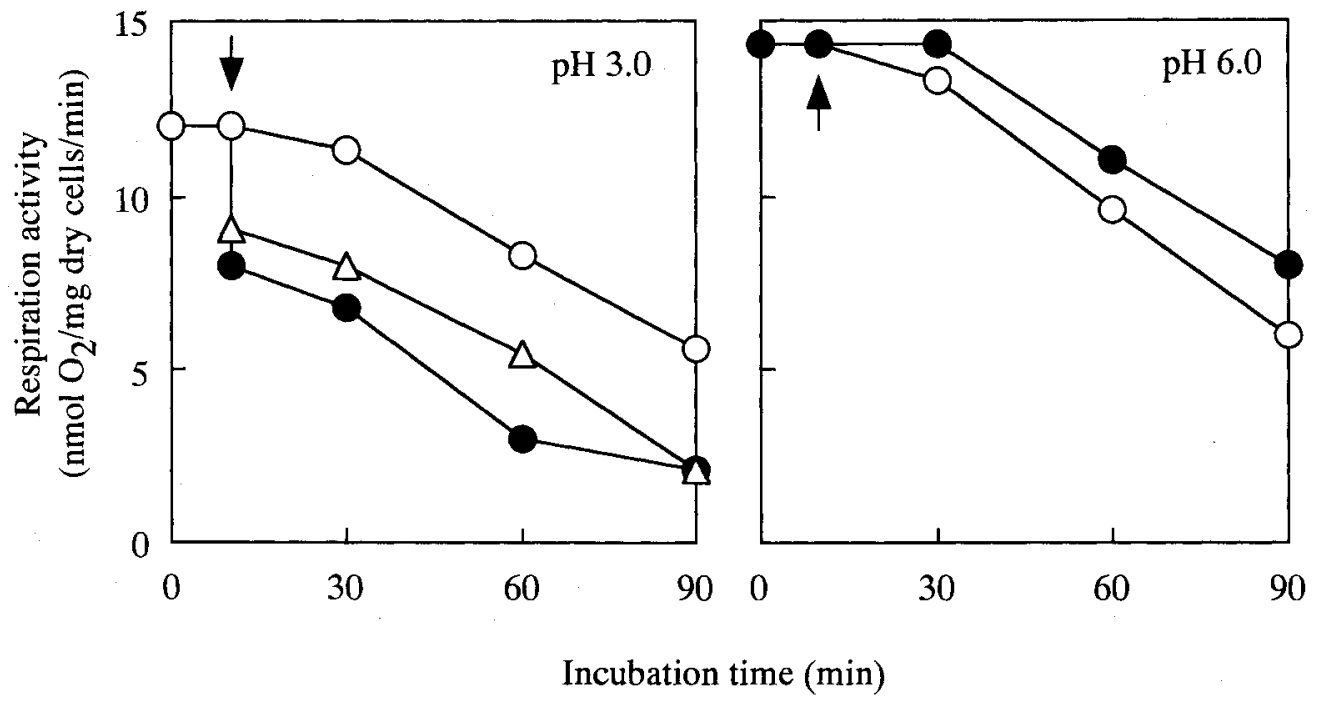

Effect on Leakage of Cellular Constituents from the Cells

Leakages of phenolsulfate-positive, or dye binding reagent-positive materials from cells were tested by incubating the yeast cells with anhydrofulvic acid at $25 \mu \mathrm{g} / \mathrm{ml}$. Anhydrofulvic acid did not cause the leakage of these substances from the cells, indicating no disturbance of the cell membrane (data not shown).
Effect on Cellular Respiration

Anhydrofulvic acid inhibited endogenous cellular respiration by 36 and $67 \%$ at 6.25 and $25 \mu \mathrm{g} / \mathrm{ml}$, respectively, as described in Table 3 . The respiration assay was performed using cells exposed with anhydrofulvic acid for 1 hour. Such short period exposure of anhydrofulvic acid might only cause weak inhibition in respiratory activity. Growth inhibition of C. utilis ATCC 42402 cells was observed after 2-days cultivation. Thus, this weak inhibition was thought 
Table 4. Effects of anhydrofulvic acid on NADH oxidase and succinate oxidase activity of C. utilis ATCC 42402 mitochondria.

\begin{tabular}{ccc}
\hline \multirow{2}{*}{$\begin{array}{c}\text { Anhydrofulvic acid } \\
(\mu \mathrm{g} / \mathrm{ml})\end{array}$} & \multicolumn{2}{c}{ Relative activity $(\%)$} \\
\cline { 2 - 3 } & NADH oxidase & Succinate oxidase \\
\hline 0.00 & 100 & 100 \\
0.39 & 100 & 33 \\
0.78 & 100 & 17 \\
1.56 & 100 & 0 \\
3.13 & 100 & 0 \\
6.25 & 90 & 0 \\
12.5 & 85 & 0 \\
25 & 82 & 0 \\
\hline
\end{tabular}

to arrest cell growth in long period exposure. On the other hand, inhibition of exogenous respiration implied that a blockage of permeation of a nutrient into the cell membrane, a metabolic obstacle of glycolysis pathway, and/or destruction of mitochondrial function. When the inhibition of endogenous respiration was observed in addition to the inhibition of exogenous one, the action of the drug was involved in the destruction of the mitochondrial-related function. As shown in Fig. 2, the inhibition of respiration seemed to depend on low $\mathrm{pH}$ level of the medium. A decrease in the $\mathrm{pH}$ level caused an increase in both the antifungal activity and the respiration inhibition. Therefore, we regarded the principal action of anhydrofulvic acid is on mitochondrial respiration. However, at $\mathrm{pH} 6.0$, the addition of anhydrofulvic acid slightly increased endogenous respiration (Fig. 2). Uncoupling agents such as 2, 4-dinitrophenol cause the increase in the rate of oxygen consumption by uncoupling oxidative phosphorylation. C. utilis cannot anaerobically ferment maltose ${ }^{15)}$, which was contained in the malt extract medium as a carbon source. If anhydrofulvic acid acts on the yeast cells as an uncoupling agent, the growth of the strain cultured in the malt exctract medium at $\mathrm{pH} 6.0$ must be inhibited. However, such growth inhibition was not observed (Table 2). Therefore, the increase in endogenous respiration was not thought to be the primary cause of the antifungal activity.

\section{Effect on Mitochondrial Respiration}

The crude preparation of C. utilis ATCC 42404 mitochondria was used for the following assay of the electron transport chain in mitochondria. As shown in Table 4, anhydrofulvic acid strongly inhibited succinate oxidase activity, assayed with both succinate and cytochrome $c$ as respiratory substrates. The inhibition was observed at $0.39 \mu \mathrm{g} / \mathrm{ml}$, which was identical to half of the concentration of MIC against C. utilis ATCC 42404. On the other hand, it did not inhibit NADH oxidase activity even at $3.13 \mu \mathrm{g} / \mathrm{ml}$, assayed with NADH as a substrate. From these results we estimated that the active site of anhydrofulvic acid was between succinate and Coenzyme Q in the electron transport chain, in other words, succinate coenzyme $Q$ reductase (complex II). Complex II consists of four peptides, two of which are integral membrane proteins (succinate dehydrogenase) and the two others that are peripheral membrane proteins (a flavoprotein and an iron-protein) ${ }^{21}$. The chemical structure of anhydrofulvic acid seemed to be similar to that of the isoalloxazine ring in flavine adenine dinucleotide (FAD), which is covalently bound to the largest subunit of complex $\mathrm{II}^{217}$. From the analogy of the structure, anhydrofulvic acid may directly interfere with the electron transfer from succinate to coenzyme $Q$ by competing with FAD. However the inhibition mechanism on isolated succinate dehydrogenase by anhydrofulvic acid on a molecular level remains to be solved.

In our experiments, the respiration activity in isolated mitochondria was measured at $\mathrm{pH} 7.0$ and the effect of anhydrofulvic acid was remarkable. Thus, the low $\mathrm{pH}$ dependency on antifungal activity of anhydrofulvic acid seemed to be highly related to the permeability of this compound into the cell membrane. At $\mathrm{pH} 7.0$, molecules of anhydrofulvic acid exist in a dissociated form. Incoporation into the cells by passive diffusion was not expected. Undissociated form of weak acids is soluble in the membrane 
phospholipid, and was thought to enter the cells by passive diffusion across the cell membrane ${ }^{22)}$. In addition, the cell membrane does not have the incorporative ability of charged molecules into the cells except systems designed for the incorporation of targeted molecules such as amino acids ${ }^{23}$. The incorporation of anhydrofulvic acid could not use systems specific to any other molecules as an analog. Therefore, it was indicated that it could permealize the cell membrane by way of passive diffusion by repressing the dissociation of hydrogen ion in its molecules at low $\mathrm{pH}$ level. Further investigations are needed to reveal the permeability of anhydrofulvic acid into the cell membrane.

\section{References}

1) Dean, F. M.; R. A. Eade, R. Moubasher \& A. RoBERTSON: The chemistry of Fungi. Part XXVII. The structure of fulvic acid from Carpenteles brefeldianum. J. Chem. Soc. 1957: 3497 3510, 1957

2) OXford, A. E.; H. RAISTRICK \& P. Simonart: CXXXIX. Studies in the biochemistry of micro-organisms. XLIV. Fulvic acid, a new crystalline yellow pigment, a metabolic product of $P$. griseofulvum dierckx, $P$ flexuosum dale and P. brefeldianum dodge. Biochem. J. 29: 1102 1115,1935

3) SAKAI, T:; A. ICHHARA \& S. SAKAMURA: Isolation of fulvic acid from Cercospora beticola. Agric. Biol. Chem. 45: 1275 1276, 1981

4) SingH, K.; S. Sun \& C. VĖZINA: Rapamycin (AY-22,989), A new antifungal antibiotic IV. Mechanism of action. J. Antibiotics 32: 630 644, 1979

5) Besson, F; F. Peypoux, M. J. Quentin \& G. Michel: Action of antifungal peptidolipids from Bacillus subtilis on the cell membrane of Saccharomyces cerevisiae. J. Antibiotics. 37: 172 177, 1984

6) Hayashi, T.; O. Yamamoto, H. SaKaki, H. OKazaki \& A. KAWAGUCHI: Inhibition of fatty acid synthesis by the antibiotic thiolactomycin. J. Antibiotics 37: 1456 1461, 1984

7) Намамото, Т.; T. Uozumi \& T. Beppu: Leptomycins A and $\mathrm{B}$, new antifungal antibiotics. III. Mode of action of leptomycin B on Schizosaccharomyces pombe. J. Antibiotics 38: 1573 1579, 1985

8) Ping, X.; Y. Akeda, K. Fujita, T. TAnaka \& M. TANIGUCHI: The mode of action of AKD-2C, antifungal antibiotic from Streptomyces $\mathrm{sp}$. OCU-42815. J. Antibiotics 51: 275 279, 1998

9) Taniguchi, M.; Y. Yano, E. Tada, K. Ikenishi, S. Oi, H. HaRaguchi, K. Hashimoto \& I. Kubo: Mode of action of polygodial, an antifungal sesquiterpene dialdehyde. Agric. Biol. Chem. 52: 1409 1414, 1988
10) Dubois, M.; K. A. Gilles, J. K. Hamilton, P. A. Rebers \& F. SMITH: Colorimetric method for determination of sugars and related substances. Anal. Chem. 28: 350 356,1956

11) BRADFORD, M. M.: A rapid and sensitive method for the quantitation of microgram quantities of protein utilizing the principle of protein-dye binding. Anal. Biochem. 74: 248 254, 1976

12) Ueki, M. \& M. TAniguchi: The mode of action of UK-2A and UK-3A, novel antifungal antibiotics from Streptomyces sp. 517-02. J. Antibiotics 50: 1052 1057, 1997

13) Bruinenberg, P. M.; J. P. van Dujken, J. G. Kuenen \& W. A. SCHEFFERS: Critical parameters in the isolation of mitochondria from Candida utilis grown in continuous culture. J. Gen. Microbiol. 131: 1035 1042, 1983

14) Bruinenberg, P. M.; J. P. VAN DiJken \& W. A. SCHEFFERS: An enzymatic analysis of NADPH production and consumption in Candida utiltis. J. Gen. Microbiol. 129: 965 971, 1983

15) UdEN, N. VAN \& H. BUCKLEY: Discussion of the genera of asporogenpus yeasts not belonging to the Sporobolomycetaceae. Genus 2. Candida Berkhout. In The yeasts. A taxonomic study, $E d$., J. LODDER, pp. 891 1082, North-Holland Publishing Company, Amsterdam, Holland, 1970

16) Yamaguchi, M.; S. Katayama, T. Todoroki \& T. Watanabe: Total synthesis of fulvic acid. J. Chem. Soc., Chem. Commn. 23: 1565 1566, 1984

17) Yamaguchi, M.; S. Katayama, T. Todoroki \& $T$. WATANABE: Studies on the synthesis of heterocyclic compounds containing benzopyrone. Part 5. Total synthesis of fulvic acid. J. Chem. Soc. Perkin Trans. I. 2: 389 394, 1984

18) Sofos, J. N. \& F. F. Busta: Sorbates. In Antimicrobials in Food. Ed., A. L. Branen \& P. M. Davidson, pp. 141 175, Dekker, New York, 1983

19) Krebs, H. A.; D. Wiggins, S. Sole \& F. Bedoya: Studies on the mechanism of the antifungal action of benzoate. Biochem. J. 214: 657 663, 1983

20) Kubo, I. \& S. H. LEE: Potentiation of antifungal activity of sorbic acid. J. Agric. Food. Chem. 46: 4052 4055, 1998

21) SCHEFfer, I. E.: Molecular genetics of succinate: quinone oxidoreductase in eukaryotes. Prog. Nucleic. Acid. Res. Mol. Biol. 60: 267 315, 1998

22) WARTH, A. D.: Transport of benzoic and propanoic acids by Zygosaccharomyces bailii. J. Gen. Microbiol. 135: $1383 \sim 1390,1989$

23) Iglesias, R.; J. M. Ferreras, F. J. Arias, R. Munoz, M. ANGeles-Rojo \& T. Girbes: Effect of L-azetidine-2carboxylic acid on the activity of the general amino acid permease from Saccharomyces cerevisiae var. ellipsoideus. Arch. Microbiol. 155: 320 324, 1991 